\title{
The experience in reconstructing of the head of Elasmotherium (Rhinocerotidae)
}

\author{
Vadim V. Titov*, Vera S. Baigusheva \& Roman S. Uchytel’
}

\begin{abstract}
We have reconstructed Elasmotherium's head based on complete intact skulls morphology analysis. The bony protuberance on the frontal bone was covered with a horny substance that protected the dome's relatively thin bones. The keratinized cover grew from the base, clearly visible in the lower part of the bony dome, and its top was displaced dorso-aborally. The dome's inner surface was an overgrown nasal cavity and served to intensify sense of smell, and, possibly, enhance sounds emitted. A relatively small narrow terminal horn-like cornified pad was attached at nasal and intermaxillary bones' end, it served to loosen and dig up soil for lants' succulent underground parts searching. Powerful muscles were especially prominent on the neck, they used to carry out lateral and dorsolateral movements of the head.
\end{abstract}

How to cite this article: Titov V.V., Baigusheva V.S., Uchytel' R.S. 2021. The experience in reconstructing of the head of Elasmotherium (Rhinocerotidae) // Russian J. Theriol. Vol.20. No.2. P.173-182. doi: 10.15298/ rusjtheriol.20.2.06

KEY WORDS: Elasmotherium, Pleistocene, appearance reconstruction, skull, muscles, habit of life.

VadimV.Titov[vvtitov@yandex.ru], Southern Scientific Centre RAS, Chekhov str. 41, Rostov-on-Don 344006, Russia; Southern Federal university, Rostov-on-Don, Russia; Vera S. Baigusheva, [paleorostov@yandex.ru], Azov Historical, Archaeological and Paleontological Museum-Reserve, Moskovskaya str. 38/40, Azov 346780, Russia; Roman S. Uchitel', [roman.uchytel@gmail.com],Prehistoric Fauna Studio, Klochkivska str., 148 A, Kharkiv 61145, Ukraine.

\section{Опыт реконструкции головы Elasmotherium (Rhinocerotidae)}

\section{В.В. Титов*, В.С. Байгушева, Р.С. Учитель}

\begin{abstract}
РЕЗЮМЕ. На основании анализа морфологии нескольких целых черепов Elasmotherium sibiricum выполнена реконструкция головы эласмотерия. Вздутие лобных костей было покрыто роговым веществом, защищавшим относительно тонкие кости купола. Роговой слой нарастал от основания, хорошо заметного в нижней части костного купола, и его верхний конец был смещён дорзо-аборально. Внутренняя поверхность купола являлась разросшейся носовой полостью и служила обострению обоняния, и, возможно, усилению издаваемых звуков. На конце носовых и межчелюстных костей крепилась некрупная узкая терминальная рогоподобная ороговевшая подушка, служившая для рыхления и раскапывания почвы в поисках сочных подземных частей растений. На шее особо выделялись мощные мышцы, осуществляющие латеральные и дорзо-латеральные движения головы.
\end{abstract}

КЛЮЧЕВЫЕ СЛОВА: Elasmotherium, плейстоцен, реконструкция внешнего вида, череп, мышцы, образ жизни.

\section{Introduction}

The rhinoceros Elasmotherium is one of the most enigmatic Eurasian Pleistocene large ungulate. Due to the peculiar structure of the skull and the domeshaped protuberance in the frontal region of the skull, it is sometimes called the "dome-forehead rhinoceros" (Teryaev, 1948). Since there are no analogues of this animal in the modern fauna, there are a number of reconstructions of this animal appearance, which often

\footnotetext{
* Corresponding author
}

contradict each other. The history of the transformation of views on the appearance of Elasmotherium is described in sufficient detail in a number of works (Teryaev, 1948; Mazza \& Azzarolli, 1993; Zhegallo et al., 2005; Shvyreva, 2016). The lifestyle of Elasmotherium was associated with movement in open steppe landscapes (Flerov, 1953; Svistun, 1973; Shvyreva, 2016) or with a semi-aquatic lifestyle in near-water stations and overflow lands covered with dense near-water vegetation such as reed and rush (Teryaev, 1948). Almost all researchers hold to the point of view of the elasmotherium's nutrition 
in the lower vegetation layer based on the angle of the plane of the occipital bone with the line of the skull base, which exceeds $90^{\circ}$ and usually amounts to $105-115^{\circ}$ (Shvyreva, 2016). The woolly rhinoceros Coelodonta antiquitatis Blumenbach, 1799 and the modern white rhinoceros Ceratotherium simum (Burchell, 1817) have similar indicators of this character, indicating a low position of the head in relation to the body.

There is no concurrent view about Elasmotherium's feeding's nature. Brandt (1878a, b) believed that Elasmotherium were typical herbivores. Some modern researchers suggest that the features of the teeth of these animals indicate that they were typical grazers and that the conversion to a browser type of diet could lead to their death (Rivals et al., 2020). According to our preliminary investigations of enamel microwear of E. caucasicum and E. sibiricum the characters of teeth wearing falls within the upper limits of variability in herbivores and is close to mixed feeders animals consuming various types of vegetation (Baigusheva et al., 2011). However, this type of dietary analysis does not indicate the specific type of consumed vegetation. It only determines the amount of abrasive material and the vegetation layer on which the animals ate during the period prior to death (Solounias \& Semprebon, 2002). According to these data, a significant amount of abrasive material (sand) was present in the food of the elasmotheriums, more than that of the most part of grazers. This indirectly testify to the possibility of feeding of Elasmotherium by the underground parts of plants, too.

Teryaev (1948), supposing a "hippopotamus" way of life of humpbacks, believed that the basis of their food was lush greenery and rootstocks of aquatic and near-water plants. Zhegallo and coauthors (Zhegallo \& Noskova, 2001; Zhegallo et al., 2005) developed this idea, considering the steppe landscape zone with intrazonal near-water biotopes of river floodplains, meadows, and overgrown ponds to be the habitat of Elasmotherium. According to these authors, these forage lands used by the Elasmotherium as preferred feeding places for the underground parts of aquatic and semi-aquatic plants. We adhere to the repeatedly expressed point of view that a number of morphological features (wedge-shaped structure of the skull with keratinization at the very end of the snout, large anterior outgrowths of the orbits, hypsodont teeth, a highly developed sense of smell, significant development of the lateral muscles of the neck, etc.) in conjunction with limbs adapted for movement on a solid substrate allowed Elasmotherium to actively feed by underground parts of plants in the zone of open and semi-open landscapes (Flerov, 1953; Titov, 2008; Shvyreva, 2016). The study of stable isotopes $\delta^{13} \mathrm{C}$ and $\delta^{15} \mathrm{~N}$ from the remains of Elasmotherium sibiricum Fisher, 1808 showed that these animals' diet was markedly different from other Pleistocene rhinoceroses, but it does not exclude underground non-photosynthetic parts of plants. It turned out that the values of stable isotopes $\delta^{13} \mathrm{C}$ and $\delta^{15} \mathrm{~N}$ in E. sibiricum are most similar to those in Saiga antelope (Kosintsev et al., 2019).

The origin of the Elasmotherium is rather ancient. The Elasmotheriinae lineage separated from the other rhinoceros long ago. This happened presumably in the Early Oligocene (Antoine, 2002; Shvyreva, 2016) or even in the Eocene (Kosintsev et al., 2019). During their independent evolution, Elasmotheriinae have acquired a number of morphological features that distinguish them from other representatives of Rhinocerotidae. The genus Elasmotherium probably appeared in the late Pliocene.

Elasmotherium remains are known within a rather vast territory - from the North-Western Black Sea Region to Eastern Asia (Kožamkulova, 1981; Shvyreva, 2016). The most finds of E. sibiricum comes from Western Siberia and the Northern Caspian Region. However, most often, the skulls' cerebral parts are in museum's collections. Due to the dome bone's thinness, the skull often broke at level of its posterior edge at frontal and parietal bones' junction. There are few complete skulls of this animal. There are no known intact skulls of older members of the genus (Baigusheva et al., 2018). Finds of incomplete skulls of $E$. cf. caucasicum (locality Tokmak, Zaporozhye Region, Ukraine; collection of the National Science and Natural History Museum of the National Academy of Sciences of Ukraine, Kiev; Svistun, 1973) and E. caucasicum Borissiak, 1912 (locality Sinyaya Balka, Taman Peninsula, Russia; collection of the Azov Museum-Reserve) suggest that there are no significant differences in the general morphology of the skull comparing with that of $E$. sibiricum.

The Elasmotheriini skull, described from the Late Miocene locality Dingbian (Shaanxi, NW China), as a holotype of the new taxon «Elasmotherium primigenium» (Sun et al., 2021), is not considered in this article. In our opinion, the taxonomic definition of this find is premature. At the same time, it should be noted that the Late Miocene and Pliocene representatives of the Tribe (genus Sinotherium) had, in general, similar characteristics of the skull (Deng et al., 2013), which we draw attention to in this work.

\section{Materials}

The base for the reconstruction were the almost complete skulls of males E. sibiricum from the Lower Volga Region (Sarepta locality, Volgograd Region, Russia; collection of the Natural History Museum (NHM), London, PV M 12429; Antoine, 2002), Novouzensk (Saratov District, Bolshoy Uzen' River, collection of the Saint Petersburg State Mining Institute (MM) No.57/357 and No.66/357), and Western Kazakhstan (Akzhar River, Akmolinsk District, Kazakhstan; collection of the Museum of Zoology of Kazakhtsan (MZK), Almaty; Tleuberdina \& Nazymbetova, 2010), on which the nasal and premaxillary bones have been preserved (Figs. 1, 2). We also used skulls with varying degrees of damage, but they allowed to restore most of the head's morphology. They originate from Stavropol Region (Zelenokumsk; collection of the Stavropol State Museum-Reserve, Stavropol, No.19907; Shvyreva, 2016), the Lower Volga Region (collection of the Paleontological institute RAS, Moscow (PIN); male and female), in particular from 


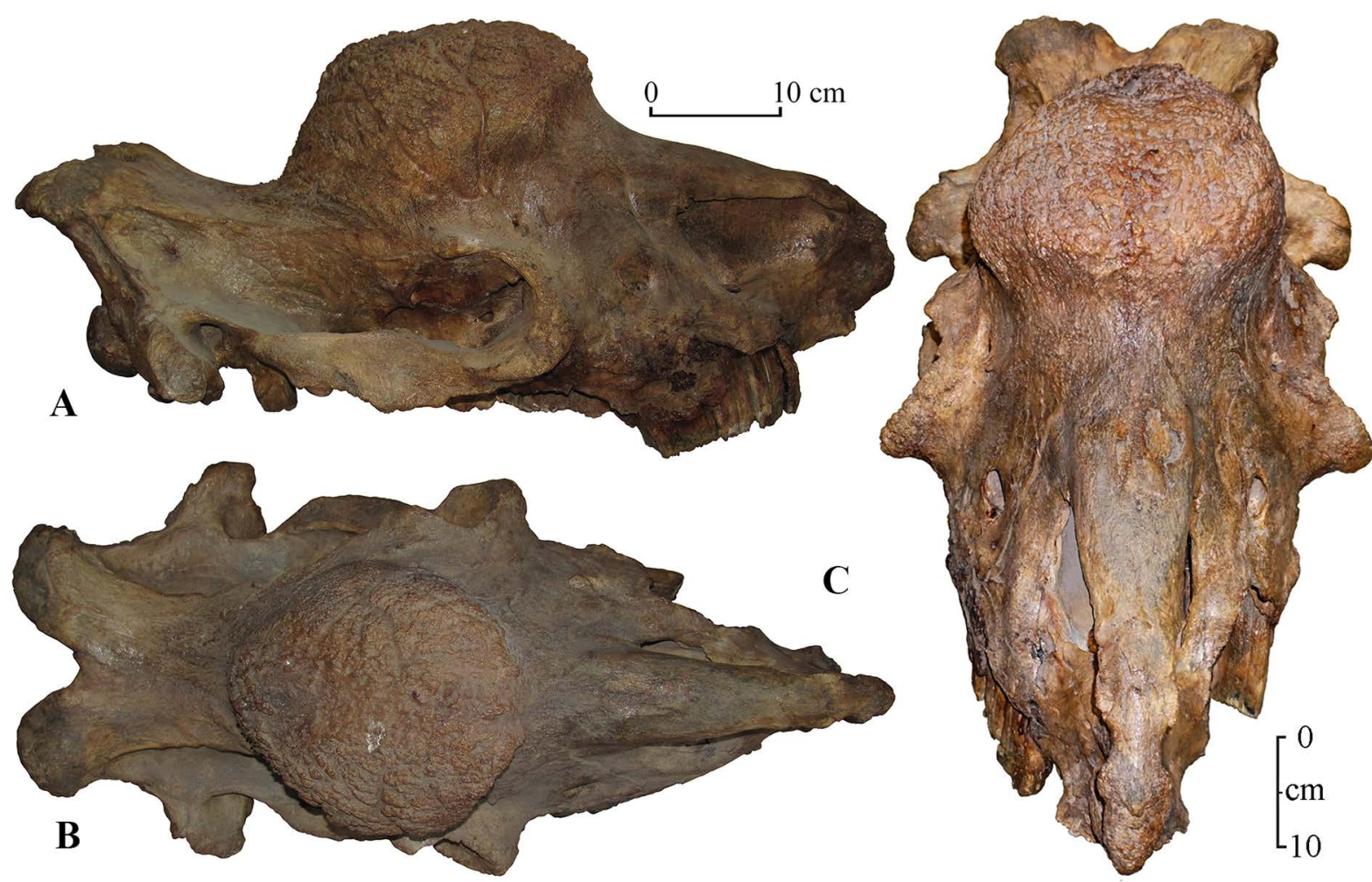

Fig. 1. Skull of Elasmotherium sibiricum from Western Kazakhstan, Akzhar River, Akmola Region, coll. MZK. A - lateral view, B - dorsal view, C - rostral view.

Sarepta (collection of the Zoological Institute RAS (ZIN), Saint Petersburg, No.10792), Verkhniy Kolyshley (Saratov Regional Local History Museum No. 8470), and Western Kazakhstan (Atyrau (formerly Guryev); collection of the V.I. Vernadsky State Geological Museum, Moscow (GGM) No.32-261 / PV-167).

Due to the deficiency of data on detail investigation of topographic anatomy of head and neck of rhinoceroses, we used the muscles' terminology of this body's part from the horse's anatomy (Popesko, 1961). The measurement were taken by Guerin (1980) and Shvyreva (2016).

\section{Description}

A detailed description of the Elasmotherium skulls and vertebrae is given in some papers (for example, Svistun, 1973; Shvyreva, 2016). In this work, we focus on those parts of the skull that allow us to reconstruct the features of the elasmotherium head.

Skulls are large and elongated. The length of the skulls of E. sibiricum males (from the localities of Sarepta, Zelenokumsk, Atyrau, Akzhar) reaches 86-89 cm. The ratio of skull width to length is less than $50 \%$. The width at lateral occipital tubers reaches $237-380 \mathrm{~mm}$, and the width of a skull at the level of mastoid bones 298-486 mm (Shvyreva, 2016; our data). The facial part of the skull is longer than the cerebral one. The nasal bones are long, narrow, tapering anteriorly and rostrally descending below the level of the parietal bones. A solid bony septum divides the nasal cavity and the dome cavity into the right and left parts. The thickness of this septum in the front reaches $32-33 \mathrm{~mm}$, in the posterior direction it becomes thinner and in the skull's dome it is $9.6 \mathrm{~mm}$ thick (in specimen from Atyrau).

One of the most important distinguishing features of the elasmotheriums' skulls is the presence of a bony protuberance on the frontal bone, which occupies almost the entire width of the dorsal part of the skull's facial part (except eye orbits). The dome is analogous to the back horn's basis of the woolly rhinoceros. The size and shape of the bony protuberance are variable depending on both sexual and age-related dimorphism. The type of the roughness of this part of the elasmotherium's skulls is very variable. This may indicate differences in the shape of the horn structure. The rugosity surface has hummocky profile with relatively uniform distribution of bone tubercles (features by Hieronymus et al., 2009). An evident ring-shaped distribution of rugose's elements at the bone dome is not observed. Neurovascular foramens on the dome surface are no detected. The transition of rugosity to adjacent bone surfaces is inequality at different part of the dome. At the anterior and lateral surfaces of a dome it has raised edge, and it is smooth at the posterior part on the transition to parietal bones. This feature is also variable. For example, at the skull from Akzhar this raised edges are obviously developed, but at the most 


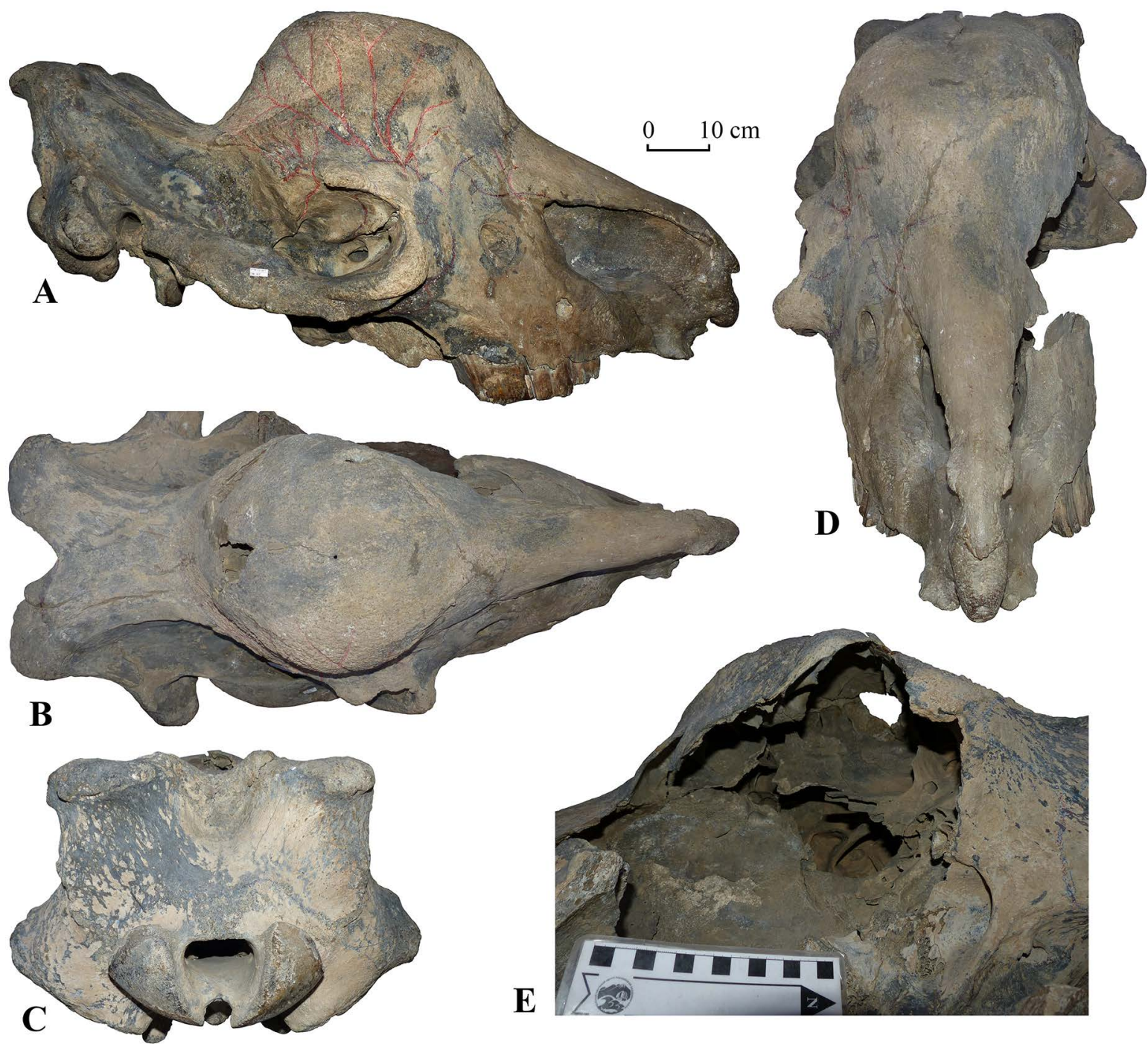

Fig. 2. Skull of Elasmotherium sibiricum from Western Kazakhstan, Atyrau, coll. GGM No.32-261/PV-167. A — lateral view, $\mathrm{B}$ - dorsal view, $\mathrm{C}$ - posterior view, D - anterior view, E - dome's inner part.

part of specimens (from Atyrau and Lower Volga River Region's localities) it is weakly marked. On some finds (for example, on specimen from Akzhar), the roughness is very markable, while on other skulls, even with large protuberances, which are attributed to males, the surface has moderate irregularities. On the female skull from the PIN collection only slight roughness is visible on the dome. The roughness on the anterior surface of the dome is less developed than on the dorsal and posterior parts. In many specimens, the lower border of the roughness is clearly visible, it is slightly higher than the dome's base in anterior and lateral sides, and in the posterior part extends to the anterior portion of the parietal bones. In some finds diagonal grooves are clearly visible on the aboral part of the place of attachment of the horn structure in the region of the border of the frontal and parietal bones, they converge medially with the posterior ends.
The bony protuberance's diameter at the base ranges from 25 to $35 \mathrm{~cm}$ (depending on the skull's size). The thickness of the frontal bone of the dome is $8-9 \mathrm{~mm}$ from anterior, 6-13.5 $\mathrm{mm}$ from the lateral (on average, $8.5 \mathrm{~mm}$ ) and 5-16 $\mathrm{mm}$ from posterior sides. Only when the frontal bone passes to the nasal, lacrimal and parietal bones its thickness increases.

There are grooves sulci on lateral and partially on dorsal and posterior surfaces of the dome, it allows to restore the largest arteries of the domed protuberance on the skull. In whole, nevrovascular grooves are sparse and its orientation is anastomosing. The main blood supply to this part of the skull was carried out by the dorsal nasal artery arteria dorsalis nasi, which is divided into branches — the anterior ramus anterior and the posterior ramus posterior at the orbit's upper edge level. The anterior one approaches the dome's anterior base. 
A vessel branche forward from it, going to the posterior edge of the nasal notch. Posterior branch a. dorsalis nasi is subdivided into 3-6 large arteries (their number may vary in different individuals) feeding the lateral, dorsal and posterior parts of the dome. Grooves from large vessels are noted not on all specimens at the top of the protuberance.

The rostral part of the nasal and premaxillary bones has a well-pronounced roughness, often equipped with a rounded hook-shaped outgrowth. The width of the anterior part of nasal bones is rather small and reaches 48-49 $\mathrm{mm}$. The shape of this platform for the attachment of the horn-like cornified pad is very variable on all 5 known finds with this part of the skull preserved (Fig. 3). It indicates the variability of the nasal terminal horn structure. The nasomaxillary notche incisura nasomaxillaris are high and deep, it indicates a presence of wide and mobile nostrils.

The partially destroyed lateral wall of the dome on some finds (in particular, on the skull from Atyrau) makes it possible to clearly see a structure of the nasal cavity and the cavity of the dome (Fig. 2E). Inside the domed protuberance, there are cellular thin-walled bony outgrowths formed by the frontal concha sinuses conchalis dorsalis and the maxillary sinuses sinus maxillaries in anterior, dorsal and lateral parts, as well as by the labyrinth of the ethmoid bone ethmoturbinalia in the posterior one (Figs. 4, 5). They form a single wide-meshed structure, which significantly increased the surface of the greatly enlarged nasal cavity and, accordingly, the mucous membranes. It should be noted that these internal outgrowths did not form a continuous structure with internal septa, which could increase the strength of the bony dome, as can be observed, for example, in the cavities of the cerebral part of the skull of elephants.

The eye orbit is limited by well-defined ridges of frontal, lacrimal and zygomatic bones at the front, above and below. Especially the orbit's anterior sides are limited by powerful outgrowths. The orbit is not closed from behind.

The parietal bones have a noticeable concavity and rise considerably towards the occipital ridge. The lateral parietal ridges are well expressed. They are almost parallel to each other in the anterior half, but diverge significantly in the transition to the occipital part.

The occipital part is low and wide. The upper part of the occipital bone bifurcates, forming two powerful lateral occipital tubers, which hang over the occipital plane and extend beyond the level of the occipital condyles. The incisures in the occipital ridge is deep. On its upper edge, the place of nuchal ligament's attachment is well expressed. There is a well-defined roughness for a muscle attachment on the occipital bone's nuchal surfaces. The mastoid processes of the temporal bone processus mastoideus are highly developed and often protrude beyond the level of the zygomatic arch and orbit.

The cervical vertebrae of Elasmotherium have a number of structural features. The first of them (atlas)

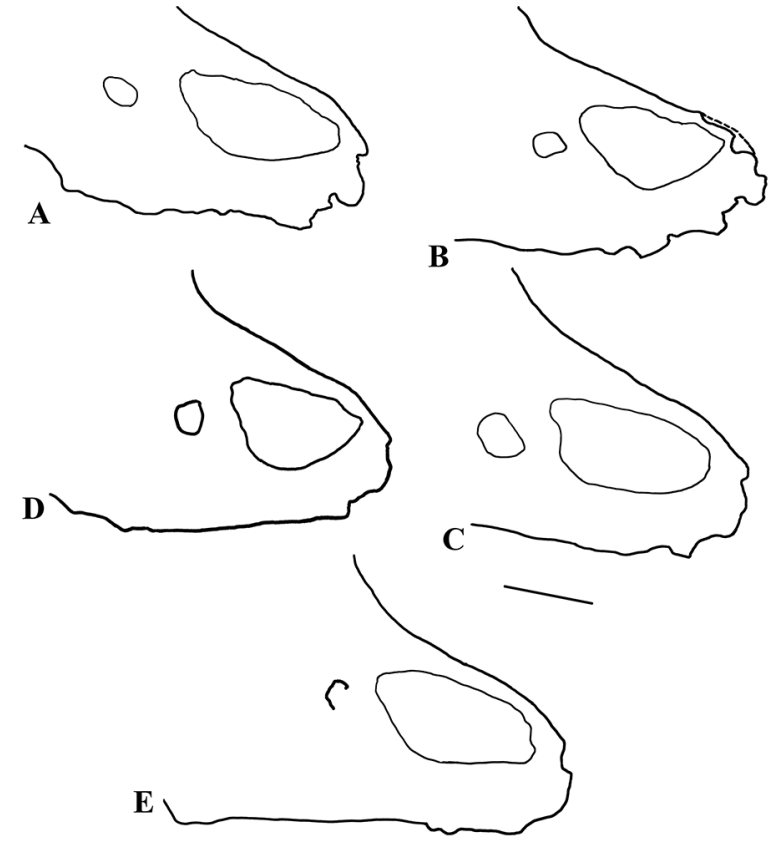

Fig. 3. The shape of the rostral part of the elasmotheriums skulls: A - Atyrau (coll. GGM No. 32-261 / PV-167), B Novouzensk (coll. MM No.57/357), C - Novouzensk (coll. MM No.66/357); D - Akzhar (coll. MZK), E — Sarepta (coll. NHM No. PV M-12429).

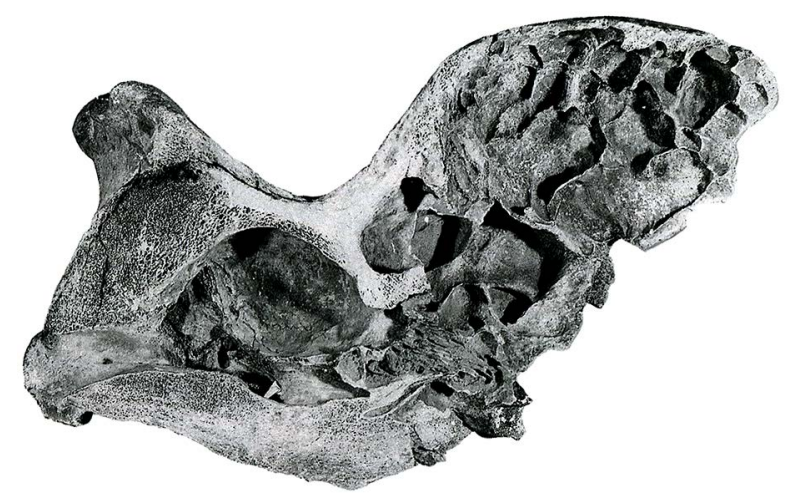

Fig. 4. Sagittal section of the skull of Elasmotherium sibiricum from the coll. ZIN (by Shvyreva, 2016).

has transverse processes up to $30 \mathrm{~cm}$ long, and has a range of wings up to $70 \mathrm{~cm}$ and exceeds the width of the skull. An atlas is aproximately twice wider the width of the skull at lateral occipital tubers and mastoid bones. The second vertebra (epistropheus) has an elongated body with a well-defined keel on the ventral surface, on the sides of which there are deep depressions. Other cervical vertebrae have high spinous processes, the length of which increases from the third to the seventh. Long narrow flattened lateral processes are distinguished on the sixth cervical vertebra (Shvyreva, 2016). 


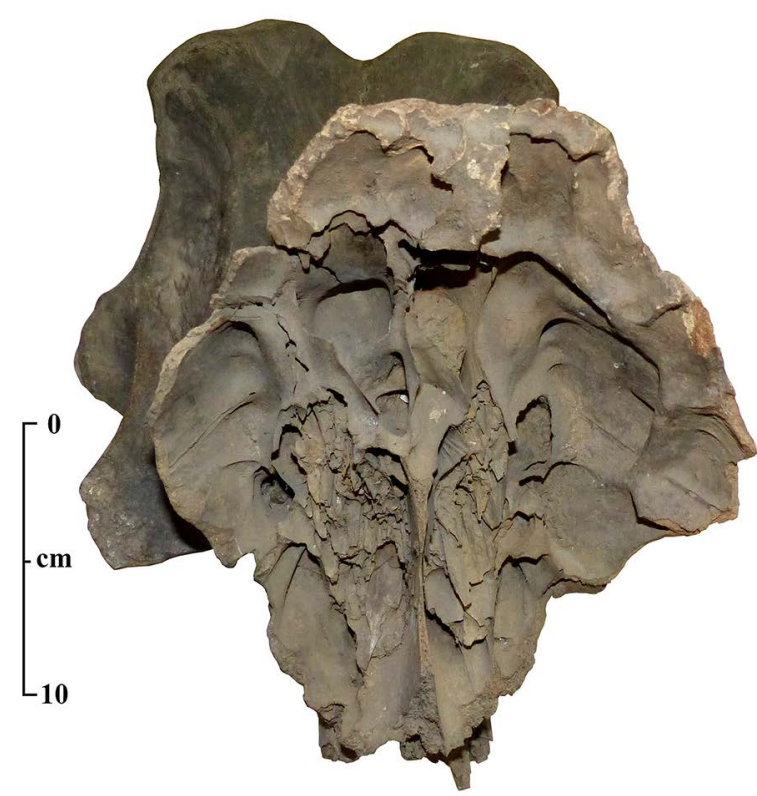

Fig. 5. Transversal section of the skull of subadult individual of Elasmotherium sibiricum at the level of the posterior part of the bony dome, coll. Saratov Regional Local History Museum No. 8470 .

\section{Discussion}

The whole skulls, used for the Elasmotherium head's external appearance reconstruction, the accumulated data and conclusions of other researchers, makes it possible to make some changes to the existing reconstructions. The point of view of the present paper's authors largely coincides with the views of Flerov (1953) and I.A. Dubrovo and V.D. Kolganov (exposition of PIN; Zhegallo et al., 2005), on the habitus of this animal. We consider a number of ideas of V.A. Teryaev and V.A. Vatagin (by Teryaev, 1948) concerning Elasmotherium head's structural features are deserved attention.

\section{The muscular system}

The skull's morphology and large muscles insertions on the skull allow us to restore the head and neck's large muscles' development. Reconstruction of muscles entire set development degree in this part of the body is not possible at this stage of the study. Dividing of the elasmotheriums' occipital ridge and separation of the nuchal areas laterally causes some different development of the ligaments and muscles connecting the skull with the cervical and anterior thoracic vertebrae.

Some semblance of a bifurcated occipital ridge into two lateral tubers in Elasmotherium is observed in wild boars, they often break surface layer of the greensward when searching food. On pigs' skulls, the lateral parts of occipital ridge are also deflected backward. The wellpronounced rugosity in the upper part of the incisure in the occiput of Elasmotherium indicates the attachment of the dorsal raphe of the strongly developed nuchal occipital ligament ligamentum nuchae. The medial fibers of the trapezius muscle and the intertwined tendons of the splenius muscle of the head musculus splenius capitis and the rhomboid minor $m$. rhomboideus are attached to it. The nuchal ligament helps to hold the heavy head and less actively use the muscles of the neck and back, connecting the head's back and the spinous processes of all cervical vertebrae. It is required for running animals, and accommodates the lowered head in the grazing position. Bundles of the splenius muscle $m$. splenius capitis extend from the tendinous bundles of the nuchal funiculus attached to the nuchal surfaces under the occipital lateral tubers.

The occipital bone's nuchal surfaces, on which the roughness is expressed, are also the place of $m$. semispinalis capitis head semispinal muscle's attachment, which connects the skull with the transverse processes of three-four posterior cervical vertebrae and five anterior thoracic vertebrae. The upper fasciculus of splenius muscle $m$. splenius capitis is attached to the well-developed lateral tubers of the occipital crest. It connects the occiput with the transverse processes of the first five cervical vertebrae, including the alas wings. Here, the cranial oblique muscle of head $m$. obliquus capitis cranialis fasten, which originates at the cranial edge of the atlas wing. It is possible that the semispinal muscles of the head $m$. semispinalis capitis, partially attached to the lateral parts of the occipital crest, too. These portions of the muscles facilitated to the spinal column upper part extension and also pulled the head back, keeping it in the overturned position.

Elasmotherium has well-defined mastoid processes of the temporal bone processus mastoideus. They suppose a significant development of dorsal band of cervical muscles: one of the tendinous branches of the longissimus muscle of a head $m$. longissimus capitis as well as the head part of the splenius muscle $m$. splenius, which go to the transverse processes of the cervical vertebrae, and also participates in head's lateral movements.

In general, the well-developed lateral muscles of the neck medial and lateral groups allowed the animal to perform head's powerful movements in the lateral and dorsolateral directions in addition to the conventional dorsoventral ones. In elasmotheriums there is an increase in the arm of the interaction lever of the first cervical vertebra and the skull (occipital tubers and mastoid bones) in the lateral plane compared to other rhinos. For example, the width of the atlas of Coelodonta antiquitatis is 319-391 cm (Garutt, 1998), which is on average almost twice less than that of Elasmotherium sibiricum.

\section{Keratoid covering of the dome}

We think, that the Elasmotherium's dome was covered with a keratoid substance that protects this thin-walled part of the skull, which is vitally important for animals.

To search for an analogy of the characteristics of this structure at Elasmotherium, it is logical to look for it among other rhinos. In modern representatives of the 
Rhinocerotidae, horns are a cornified papillary epidermal appendages. It is strongly convergent with similar tissues, such as ungulate hoof wall and bovid artiodactyls horns (Hieronymus et al., 2006). As mentioned above, the divergence of the lineage of Elasmotheriinae and other Rhinocerotidae occurred at the end of the Paleogene (30-40 million years ago). In Rhinocerotinae, the first appearance of derived dermal support of the epidermal horns is attributed only to the early Miocene (16-20 Ma) (Hieronymus, 2009). Therefore, it is possible that the nature of the keratinized cover of the skull's dome of Elasmotherium differed from that of other rhinos.

According to Hieronymus (2009) the presence of an annular (ring-shaped) distribution of rugose bone is one of the main indicators of a keratinized horns' presence on the skull's bones of rhinos. However, our analysis of the character of rugosities at the places of attachment of the horns on the skulls of $C$. antiquitatis shows that the obvious ring character is not always observed, especially on the same of females and young animals. Here we can observe rather the radial ordering of bone exostoses, which often coincides with the presence of bilateral symmetry of the pattern. In general, at known taxa of rhinos with a clear presence of nasal epidermal horns there is a compact area on the nasal bones with a relatively ordered arrangement of elements and often with annular rugosities. Horn's basis is a fairly dense layer of bone. The more developed horn correlates with more pronounced relief of the rugosity (for example, as in the male of woolly rhinoceros).

There are differences in the places of Elasmotheriums' "horns" attachment and horned rhinoceros. The absence of a clear annular or radial structure of rugosity on the elasmotherium skull, together with rather thin walls of the dome, indicates the absence of a epidermal horn on frontal bones. It should be noted that the presence of individual variability of the of rugosity's appearance and its certain orientation, together with a highly developed circulatory system, indicates that an epidermal integumentary pad but not dermal armor was appeared here. A comparative similarity of the rugose structure is observed on the frontal boss of african buffalo Syncerus caffer, and muskox Ovibos moschatus. In both cases, the bone that supports the heavily cornified pad of epidermis is highly vascular and have an uneven surface (Hieronymus et al., 2009). The difference is observed in the presence of rounded knobs on the skull bones of Elasmotherium, but not depressions.

Some analogy of the growth and development of such a structure can be found in bovids. It is known that in Bovidae, for example, in representatives of the genus Bison, horny sheaths grow on horncores (bony outgrowths of the frontal bones) gradually, shifting from the base to the end of the horn. It is known that in modern rhinos, horn also grows from base (Hieronymus, 2006; Hieronymus et al., 2006). For this purpose, furrows and ridges are formed on them, along which the sheaths growing at the base is shifted. Numerous blood vessels pass through the cavities in the horncore. They go out and lie in the canals on the distal half of the horn, providing active blood supply of the terminal part in area of core intensive growth. The burr represented by a tubercles' ring on the core, is located at the place of the keratoid substance formation. This burr development is more noticeable on adult males' horncores. It is poorly developed in young males and females. With age, a number of vascular apertures in a core decreases in the proximal part of a horn. In very old animals' bone cores' growth in length stops and their partial resorption occurs. A number of vascular apertures decreases, and the holes and channels in the core are closed. The keratoid substance after the stopping of growth on the horn surface, begins to chap and peel off, almost does not regenerate. The horn sheaths in bovids does not correspond to the bone cores in length. For example, bison's horny sheaths are longer than their horncores. The ones of adult animals can be longer on average by $1 / 3$ of their bony base (Sokolov, 1979: pp. 31-32).

The presence of varying degrees of rugosity's rate on the surface of the bone's dome in Elasmotherium indicates an individual, age and sexual variability of the cornified pad. We can assume that in young, very old individuals and females, the dome was covered with a relatively thin keratin layer. It is logical to assume a greater degree of development of this structure in adult males. The presence of diagonal grooves on the aboral part of the rugosity surface, partially extending from the back of the dome-shaped protuberance to the parietal bones, may indicate that the upper end of the more developed pad was displaced dorso-aborally. Indirect evidence of the presence of a relatively thin keratin layer of the dome is a trace of intravital damage on the anterio-lateral surface of the dome at the skull from Atyrau (Fig. 1). This hole with traces of overgrowth is interpreted as a injury's consequence (Zhegallo et al., 2005).

\section{Bone dome}

The Elasmotherium dome surface is covered with roughness. But the degree of its intensity can vary individually, as, for example, at the attachment points of horns in woolly rhinoceros. But, at the same time, the degree of development of this roughness in Elasmotherium is never as strong as, for example, in woolly rhinoceros. The dome cavities, being a widening of the nasal cavity, in addition to enhancing the sense of smell (as pointed out by many researchers of Elasmotherium) could also function as sounds amplifier. We observe that the dome greatest development occurs for adult males. On young animals' skulls and on the skull from the collection of the PIN, which is attributed to the female (Zhegallo et al., 2005; Shvyreva, 2016), the dome cavity is not so hypertrophied. Probably, a relatively small widening of this cavity was enough for elasmotherium for normal life. For males, to attract females and control of the territory, it was necessary to reproduce louder sounds, which were amplified with the help of a volumetric dome. In addition to protecting the thin-walled bone dome from mechanical influences, the overgrown keratoid pad in Elasmotherium could also serve to protect the neck from the attack of predators. 
Rostral part of the skull

The presence of a solid internasal septum in Elasmotherium suggests significant loads at the muzzle end. Despite the fact that recent rhinos are also capable of producing significant effects with the nasal horns, their internasal septum remains cartilaginous throughout their life (Garutt, 1998). A similar development of internasal septum is characteristic for woolly rhinoceros, which had a large anterior horn, used as well as for shoveling snow and an upper layer of greensward. At the anterior end of the nasal and intermaxillary bones of the Elasmotherium, there are clearly visible thickenings with a rough surface, which suggest the attachment of small and narrow horn formations to them. Taking into account the supposed active use of the end of the muzzle for raking and digging a soil to find underground parts of plants, it is possible that a horn was used for this purpose. In Teryaev (1948), on reconstructions the nasal horn is displaced dorsally rather high, like for recent rhinos. Brandt (1878b) suggested the presence of a small nasal horn, located at the muzzle tip and representing a low keratoid plate. However, on the Rashevsky's engraving, supervised by Brandt, such a horn almost did not discernible. The authors know about five skulls with intact rostral part (Fig. 3), their analysis allows us to clarify the anterior horn-like conformation's position. The development of variable in shape thickenings and rounded hook-shaped bony outgrowths on the rostral part of the intermaxillary bones suggests the location here of a small terminal hornlike structure. The nasal bones tip, slightly protruding above the intermaxillary bones, probably acted as an upper stop for this "horn".

There are no annular distribution of rugose bone on the anterior part of the nasal bones and on the terminal part of the internasal septum. This indicates the absence of true epidermal horns. Roughness on the anterior part of the nasal bones indicates the presence of a cornified pad or cornified sheath, as well as for a keratinized covering of the dome at the frontal bones. Taking into account the different degree of the rugouse area development and the presence of bony "hooks" on the anterior edge of the internasal septum, we can assume the variable of shape and size of this terminal cornified pad, regardless of gender. The presence of pronounced bony "hooks" (for example, on the skull from Atyrau) suggests that they were a support for the horn-like structure of the cornified pad in adult individuals.

The presence of roughness on the nasal bone anterior part and the rostral part of the internasal septum also suggests the presence of a movable fleshy upper lip, which is necessary for digging out tubers and rootstocks.

\section{Food base}

Teeth of elasmotheriums have a sidewall hypsodonty with the highest crown height among ungulates. On the permanent teeth of Elasmotherium sibiricum roots did not formed at all, even on premolars, and in the Early Pleistocene E. caucasicum roots on M2 and M3 are unknown also. Such hypsodont teeth suggests intake of a highly abrasive food. Recently, more and more researchers adhere to the point of view that underground parts of plants were the nutrition basis for Elasmotherium. It is a food resource poorly consumed by other animal species. In contrast to the opinion of Teryaev (1948) and Zhegallo et al. (2005), we believe that these animals harvested bulbs, tubers, or rootstocks not so much in shallow parts of water bodies as in other biocenoses. Steppes, forests and meadows are the phytocommunities rich by ephemeroids (perennial herbaceous plants with underground succulent organs). Probably, seasonality in the change of places for obtaining food was characteristic for elasmotheriums. It is also possible that the diet of these animals included aboveground parts of herbaceous plants and shrubs in smaller quantity.

Based on the characteristics noted, the head of Elasmotherium was reconstructed (Fig. 6). The skulls and mandibles of E. sibiricum were taken as a basis. The pelage, which was present on the head of representatives of this species most likely, was not taken into account in the figures presented in order to detail some morphological features. Taking into account that the roughness is much more developed on the posterior part of the bony dome and on the adjacent parts of the parietal bones, and the posterior portion of the blood vessels on the dome is more pronounced, we assume that the keratoid substance was more developed precisely on the posterior half of the dome-shaped protuberance. Probably, the uneven growth of the keratoid substance led to the displacement of the apex of the horny sheaths in the dorsal-aboral direction.

\section{Conclusions}

Representatives of the genus Elasmotherium have no analogues in the modern fauna. Elasmotheriinae separated from other branches of the Rhinocerotidae family more than 30 million years ago. During this period of evolution they acquired a number of morphological and physiological features. Therefore, during the reconstructing the external appearance of elasmotherium, one cannot fully rely on that of recent rhinoceroses or other well-studied fossil taxa (for example, woolly rhinoceros). Both the late Middle Pleistocene Siberian elasmotheriums and Early Pleistocene Caucasian ones had a wedge-shaped form of the anterior part of the skull with a small "horn" at the very end of the muzzle, well-defined anterior outgrowths of the orbits, hypsodont teeth, large olfactory lobes of the brain, hypertrophic nasal cavities, a highly developed sense of smell, and significant development of the lateral muscles of the neck. We adhere to the point of view of researchers who believed that the characteristics of the skulls and necks of elasmotheriums indicate adaptations to digging out from the soil and feeding by underground parts of plants. Bulbs, tubers, and rootstocks of perennial plants in steppes, meadows, and forest areas probably constituted a significant part of the diet of these large animals, which have occupied an unoccupied ecological niche. This allowed the Elasmotherium to exist from the end of the Pliocene to the late Pleistocene without any special 


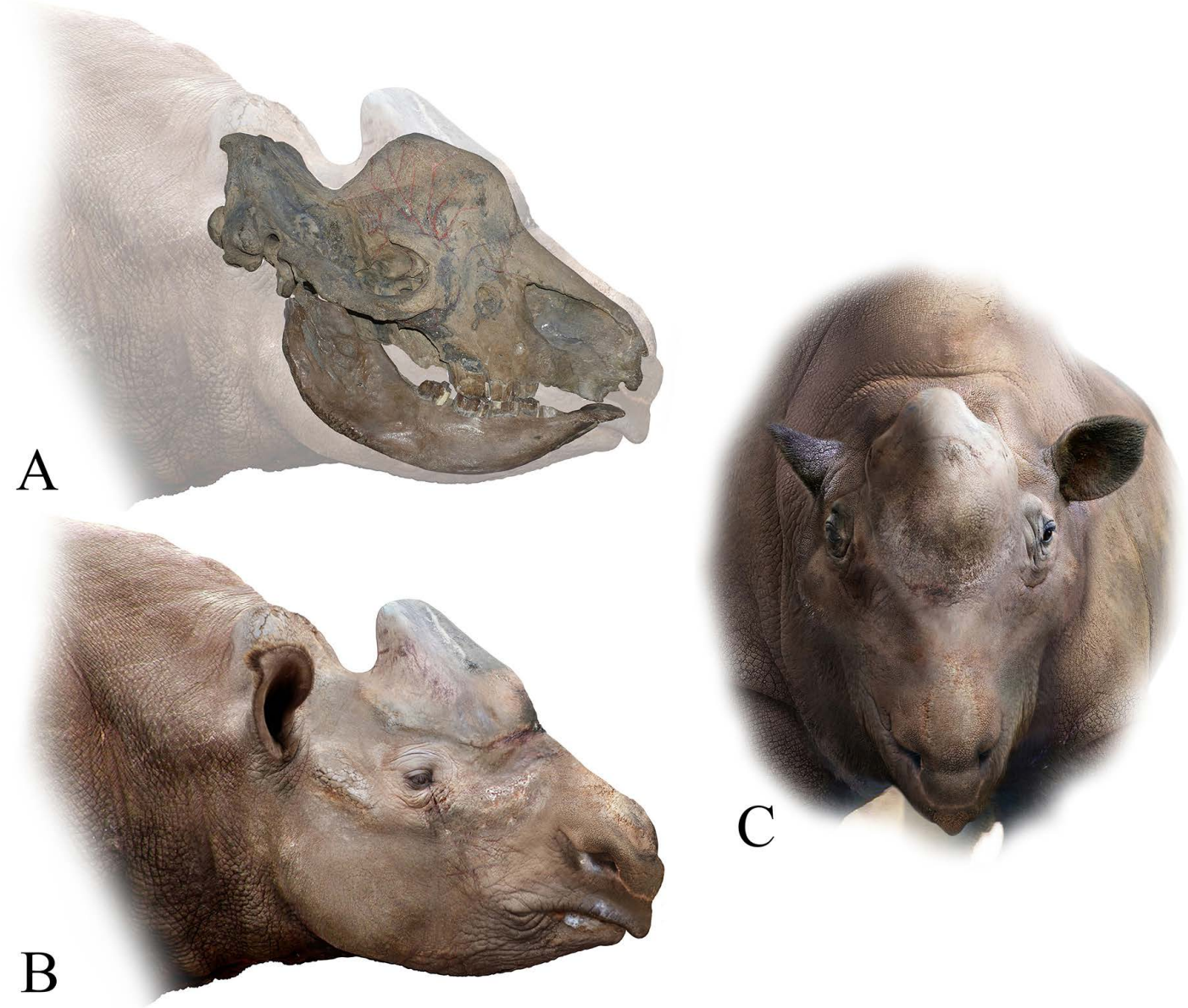

Fig. 6. Reconstruction of the head of male of Elasmotherium. Author R.S. Uchitel'.

morphological rearrangements. Late Elasmotherium differed from the early Pleistocene forms only by slightly smaller sizes, minor changes in the dentition, and, most likely, in the presence of a coat.

One of the main distinguishing features of these distinctive rhinos is a dome-shaped bony protuberance on the frontal bones, which causes major controversy among scientists and restorers. The thin walls of the bony dome in anterior, lateral and dorsal sides have an average thickness of about $1 \mathrm{~cm}$. The wide-meshed structure inside the dome, formed by overgrown thin-walled bony outgrowths of the frontal concha and maxillary sinuses, as well as the labyrinth of the ethmoid bone is not a structure of strengthening of the dome strength. This makes it possible to assume that the dome was not a place of attachment of a large horn or any other structure, but was covered with a relatively thin keratoid substance, which mainly performs a passive protective function for fragile bones. The dome inner surface was an overgrown nasal cavity, which served to intensify a sense of smell, and, possibly, to amplify sounds emitted. The cornified pad grew from the clearly visible base in the lower part of the bony dome, and its upper end was displaced dorso-aborally. The blood vessels located on the bones surface contributed to the growth and partial renewal of this formation. The different degrees of roughness intensity on the surface of the dome indicates that the keratoid cover was growing to a greater extent for males, while this process was slower for females, juvenile and old individuals.

A solid internasal septum indicates a significant load on the end of the muzzle. The presence of outgrowths and roughness on the rostral parts of the nasal and intermaxillary bones suggests a presence of a terminal horn-like structure of cornified pad and a fleshy upper lip, which participated in the process of the soil hoeing and selecting of food objects.

The significant development of the atlas transverse processes, the high spinous processes of other cervical vertebrae, as well as the massive mastoid processes of the temporal bone, the bifurcation of the occipital crest into two lateral halves indicate a presence of powerful lateral neck muscles that carry out lateral and dorsolateral head movements in addition to the conventional dorsoventral ones. The development of such a muscular system confirms the adaptability of Elasmotherium to raking the upper soil layer. 
ACKNOWLEDGEMENTS. The authors are grateful to the staff of the V.I. Vernadsky State Geological Museum (I.A. Starodubtseva), Institute of Zoology of Ministry of Education and Science of Republic of Kazakhstan (P.A. Tleuberdina), and Saratov Regional Local History Museum (A.V. Biriukov) for the opportunity to work with the material. We are thankful for Dr. P.-O. Antoine and anonymous reviewer for the helpful remarks and recommendations for the improvement of the manuscript. The study was supported by the Russian Science Foundation, project No. 16-17-10170-P.

\section{References}

Antoine P.O. 2002. Phylogénie et évolution des Elasmotheriina (Mammalia, Rhinocerotidae) // Mémoires du Muséum National d'Histoire Naturelle. Vol.188. P.1-359.

Baigusheva V.S., Timonina G.I. \& Titov V.V. 2011. [Some characteristics of the functioning and change of teeth of the Caucasian elasmotherium Elasmotherium caucasicum] // [Zoological Research for 20 years of Independence of the Republic of Kazakhstan. Materials of International Conference]. Almaty: Institute of Zoology. P.304-305 [in Russian].

Baigusheva V.S., Titov V.V. \& Timonina G.I. 2018. [Problems of species diagnosis of elasmotheriums (Rhinocerotidae, Elasmotheriinae)]//[Fundamental and Applied Paleontology. Materials of 64 Session of Paleontological Society of RAS]. Saint Petersbourg: Kartofabrika VSEGEI. P.171-173 [in Russian]

Brandt A.F. 1878a. Milleilungen uber die Gattung Elasmotherium besonders den Schaedelbau derselben // Mémoires de l'Académie Impériale des Scences de St.Pétersbourg, VII series. Vol.26. No.6. P.1-36.

Brandt A. 1878b. [Elasmotherium (fossil rhinoceros)] // Niva. No.23. P.411-415 [in Russian].

Deng T., Wang S. \& Hou S. 2013. A bizarre tandem-horned elasmothere rhino from the Late Miocene of northwestern China and origin of the true elasmothere // Chinese Science Bulletin. No.58. P.1811-1817.

Flerov K.K. 1953. [Unicorn - elasmotherium] // Priroda. No.9. P.110-112 [in Russian].

Garutt N.V. 1998. [Wolly Rhinoceros (Morphology, Systematic, Geological Significance)]. PhD Thesis. Saint Petersburg: G.V. Plekhanov Saint Petersburg State institute of mines. 247 p. [in Russian].

Guerin C. 1980. Les rhinoceros (Mammalia, Perissodactyla) du miocene terminal au pleistocene superieur en Europe Occidentale. Comparaison avec les especes actuelles // Documents des Laboratories de Geologie Lyon. No.79. Fasc.1. P.1-421.

Hieronymus T.L. 2009. Biological Sciences Osteological Correlates of Cephalic Skin Structures in Amniota: Documenting the Evolution of Display and Feeding Structures with Fossil Data. PhD Thesis. Athens: College of Arts and Sciences of Ohio University, USA. $254 \mathrm{p}$.

Hieronymus T.L., Witmer L.M. \& Ridgely R.C. 2006. Structure of white rhinoceros (Ceratotherium simum) horn investigated by X-ray computed tomography and histology with implications for growth and external form // Journal of Morphology. Vol.267. P.1172-1176.

Hieronymus T.L., Witmer L.M., Tanke D.H. \& Currie Ph.J. 2009. The facial integument of centrosaurine ceratopsids: morphological and histological correlates of novel skin structures // The Anatomical Record. Vol.292. P.1370-1396.
Kosintsev P., Mitchell K.J., Devièse Th., Plicht J. van der, Kuitems M., Petrova E., Tikhonov A., Higham Th., Comeskey D., Turney C., Cooper A., Kolfschoten Th. van, Stuart A.J. \& Lister A.M. 2019. Evolution and extinction of the giant rhinoceros Elasmotherium sibiricum sheds light on late Quaternary megafaunal extinctions // Nature Ecology \& Evolution. Vol.3. P.31-38.

Kožamkulova B.S. 1981. Elasmotherium sibiricurn und sem Verbreitungsgebiet auf dem Territorium der UdSSR // Quartärpaläontologie. No.4. P.85-91.

Mazza P. \& Azzarolli A. 1993. Ethological inferences on Pleistocene rhinoceroses of Europe // Rendiconti Lincei. Scienze Fisiche e Naturali. S.9. Vol.4. P.127-137.

Popesko P. 1961. [Atlas of Topographic Anatomy of Farm Animals. Vol.1. Head and Neck]. Bratislava: Slovak Agricultural Literature Publishing House. 215 p. [in Russian].

Rivals F., Prilepskaya N.E., Belyaev R.I. \& Pervushov E.M. 2020. Dramatic change in the diet of a late Pleistocene Elasmotherium population during its last days of life: Implications for its catastrophic mortality in the Saratov region of Russia // Palaeogeography, Palaeoclimatology, Palaeoecology. Vol.556. P.e109898.

Sokolov V.E. (ed.). 1979. [European bison. Morphology, systematic, evolution, ecology]. Moscow: Nauka. 496 p. [in Russian].

Solounias N. \& Semprebon G. 2002. Advances in the reconstruction of ungulate ecomorphology with application to early fossil equids // American Museum Novitates. No.3366. P.1-49.

ShvyrevaA.K. 2016. [Elasmotheriums of Pleistocene of Eurasia]. Stavropol: Pechatniy Dvor Publishing. 218 p. [in Russian].

Svistun V.I. 1973. [The skull of Caucasian elasmotherium (Elasmotherium caucasicum Boriss.) from Late Pliocene deposits of Zaporozh'e Region] // Vestnik Zoologii. No.2. P.53-60 [in Russian].

Sun D., Deng T. \& Jiangzuo Q. 2021. The most primitive Elasmotherium (Perissodactyla, Rhinocerotidae) from the Late Miocene of northern China // Historical biology, DOI: 10.1080/08912963.2021.1907368

Teryaev V.A. 1948. [Geological position of dome-forehead rhinoceros (elasmotherium)] // Sovetskaya Geologiya. No.34. P.81-89 [in Russian].

Titov V.V. 2008. [Late Pliocene Large Mammals from Northeastern Sea of Azov Region]. Rostov-on-Don: Southern Scientific Centre RAS Publishing. 262 p. [in Russian, with English summary].

Tleuberdina P. \& Nazymbetova G. 2010. Distribution of Elasmotherium in Kazakhstan // Quaternary Stratigraphy and Paleontology of the Southern Russia: Connections between Europe, Africa and Asia. Abstracts of 2010 Annual Meeting INQUA-SEQS. Rostov-on-Don: Southern Scientific Centre RAS Publishing. P.171-173.

Zhegallo V.I. \& Noskova Y.G. 2001. [Several morphological and functional features of skeleton of rhinoceros Elasmotherium and its ecological interpretation]// Bulleten Moskovskogo Obshchestva Ispytateley Prirody, Otdel Geologicheskiy. Vol.76. No.6. P.63-69 [in Russian].

Zhegallo V., Kalandadze N., Shapovalov A., Bessudnova Z., Noskova N. \& Tesakova E. 2005. On the fossil rhinoceros Elasmotherium (including the collections of the Russian Academy of Sciences) // Cranium. Vol.22. No.1. P.1-40. 